\section{Public health implications}

- Most women in developed countries are now offered screening for neural tube defects and affected babies are less common

- Ascertainment of all births and terminations of pregnancy affected by neural tube defects in South Australia shows that the total prevalence remained stable during 1966-91

- Birth prevalence, however, fell by $84 \%$ as a result of screening

- Serum $\alpha$ fetoprotein concentration and ultrasonography detected $85 \%$ of affected pregnancies before 28 weeks' gestation

- Coordinated population based screening programmes and registers of birth defects allow accurate assessment of effectiveness of prenatal diagnosis and preventive measures

than for spina bifida is to be expected as anencephaly is easier to diagnose by ultrasonography and it is usually associated with a high maternal serum $\alpha$ fetoprotein concentration. Serum $\alpha$ fetoprotein concentration is not often raised in closed spina bifida (which comprised $24.6 \%$ of the spina bifida cases in 1986-91). The fall in birth prevalence and the proportion of defects detected prenatally are consistent with the findings of other centres with a population based maternal serum $\alpha$ fetoprotein screening programme and wide access to ultrasound screening in pregnancy. ${ }^{210}$ Centres without a population based serum $\alpha$ fetoprotein screening programme have generally achieved a lower proportion of prenatal diagnoses. ${ }^{29}$

The impact of prenatal diagnosis on birth prevalence is dependent not only on the sensitivity of the screening programme but also on the uptake of testing by doctors and pregnant women, presentation for antenatal care in time for screening and legal termination of pregnancy, and the attitude to termination of pregnancy of couples with affected fetuses.

Our results show the value of population based registers in accurate ascertainment of birth defects, which enables assessment of the effect of preventive strategies. The centralised maternal serum $\alpha$ fetoprotein screening programme facilitated ascertainment. Folate has been shown to reduce the rate of neural tube defects when taken before conception and in the early months of pregnancy. ${ }^{120}$ There is no formal policy on the use of folate before conception in South Australia, but the Australian National Health and Medical Research Council has recommended that women who have had an affected pregnancy or have a family history of neural tube defect should be offered genetic counselling and folic acid supplements around the time of conception ( $5 \mathrm{mg}$ daily). The council has also recently recommended (115th session, Adelaide, June 1993) that women in low risk groups should take $0.5 \mathrm{mg}$ of folic acid daily around the time of conception, that all women of childbearing age should be encouraged to increase their intake of folate rich foods, and that staple foods should be fortified with folic acid.

We thank all the midwives and doctors who notified to the collections used in this study and who responded to further requests for information; the histopathologists who provided final diagnoses for the defects; the Australian Bureau of Statistics, South Australian Branch; the staff of all the departments in this study for their support and help, especially Mr Ahmad Hanieh, director of the department of neurosurgery, Professor Donald Simpson, formerly director of the department, and Professor Anthony Pollard, formerly director of the department of chemical pathology, Adelaide Children's Hospital; and Mr Adrian Esterman, principal health statistician, South Australian Health Commission for doing the Poisson regression analyses. We also thank the committee appointed to examine and report on abortions notified in South Australia for allowing us to use the abortion statistics.

1 Kirke PN, Elwood JH. Anencephaly in the United Kingdom and Republic of Ireland. $B M F$ 1984;289:1621.

2 EUROCAT Working Group. Prevalence of neural tube defects in 20 regions of Europe and the impact of prenatal diagnosis, 1980-1986. I Epidemio Community Health 1991;45:52-8.

3 Romijn JA, Treffers PE. Anencephaly in the Netherlands: a remarkable decline. Lancet 1983;i:64-5.

4 Kallen B, Lofkvist E. Time trends of spina bifida in Sweden 1947-81. I Epidemiol Community Health 1984;38:103-7.

Czeizel A. Spina bifida and anencephaly. BMf 1983;287:429.

6 Stein SC, Feldman JG, Friedlander M, Klein RJ. Is myelomeningocoele a disappearing disease? Paediatrics 1982;69:511-4.

7 Khoury MJ, Erickson JD, James LM. Etiologic heterogeneity of neural tube defects: clues from epidemiology. Am $\mathcal{f}$ Epidemiol 1982;115:538-48.

8 Bower C, Hobbs M, Carney A, Simpson D. Neural tube defects in Western Australia 1966-81 and a review of Australian data 1942-81. I Epidemiol Community Health 1984;38:208-13.

9 Bower C, Raymond M, Lumley J, Bury G. Trends in neural tube defects 1980 1989. Med F Aust 1993;158:152-4.

10 Ferguson-Smith MA. The reduction of anencephalic and spina bifida births by maternal serum alpha-fetoprotein screening. Br Med Bull 1983;39:365-72.

11 Cuckle $\mathrm{H}$, Wald $\mathrm{N}$. The impact of screening for open neural tube defects in England and Wales. Prenatal Diagnosis 1987;7:91-9.

12 Owens JR, McAllister E, Harris F, West L. 19-year incidence of neural tube defects in area under constant surveillance. Lancet 1981;ii:1032-5.

13 Centers for Disease Control. Spina bifida incidence at birth-United States, 1983-1990. MMWR 1992;41:497-500.

14 International Clearinghouse for Birth Defects Monitoring Systems. Annual report. CBDMS, 1988.

15 Gebski V, Leung O, McNeil D, Lunn D. Statistical package for interactive dato analysis (SPIDA). User's Manual, Version 6. Sydney: Statistical Computing Laboratory, 1992.

16 Holmes LB, Driscoll SG, Atkins LA. Etiologic heterogeneity of neural tube defects. N Engl f Med 1976;294:365-9.

17 Dean AG, Dean JA, Burton AH, Dicker RC. Epi Info version 5: a word processing, database and statistics programme for epidemiology on microcomputers. Stone Mountain, Georgia: USD, 1990.

18 Creasy MR, Alberman ED. Congenital malformations of the central nervous system in spontaneous abortions. 7 Med Genet 1976;13:9-16.

19 MRC Vitamin Study Research Group. Prevention of neural tube defects: results of the Mecical Research Council vitamin study. Lancet 1991;338: 131-7.

20 Czeizel AE, Dudas I. Prevention of the first occurrence of neural-tube defects by periconceptional vitamin supplementation. N Engl f Med 1992;327: $1832-5$.

(Accepted 2 fuly 1993)

\section{Corrections}

How frequently should basic cardiopulmonary

resuscitation training be repeated to maintain adequate skill?

An editorial error occurred in this paper by Hubert J J M Berden and others (12 June, $\mathrm{pp}$ 1576-7). The figure suggests that resuscitation skills were measured only once in each group at time 0 whereas two measurements were made, immediately before and after training in resuscitation was given. Before training all three groups accrued about 38 penalty points, while after training they all accrued about 15 points.

\section{Lifelong exercise and stroke}

An editorial error occurred in this paper by Roger Shinton and Gian Sagar (24 July, pp 231-4). The first sentence in the second paragraph of the methods section should have read: "Between 1 October 1988 [not 1989] and 30 September 1990 we recruited men and women who had just had their first stroke and were aged 35-74."

\section{Urinary microalbumin excretion in early pregnancy and} gestational age at delivery

An editorial and an authors' error occurred in this paper by Ivan Perry and others (14 August, pp 420-1). In the table the second quartile of distribution of albumin:creatinine ratio should be 0.35 to $\mathbf{0 . 6 2}$. In the first sentence of the second paragraph the study group was defined incorrectly; the group comprised 692 healthy nulliparous pregnant women and 11 women with chronic hypertension referred for antenatal care before 31 weeks' gestation. 